\title{
KEBIJAKAN KRIMINAL DALAM MENANGGULANGI KELEBIHAN KAPASITAS LEMBAGA PEMASYARAKATAN
}

\author{
Safaruddin Harefa \\ Universitas Mohammad Natsir Bukittinggi \\ Email: safaruddinharefa1993@gmail.com
}

\begin{abstract}
Abstrak
Penelitian ini bertujuan untuk mengetahui faktor-faktor yang mempengaruhi kepadatan lapas, kebijakan Lapas Wirogunan untuk menanggulangi kelebihan kapasitas Lapas serta bagaimana formulasi pidana dan pemidanaan untuk mengurangi kelebihan kapasitas di dalam Lapas. Penelitian ini menggunakan penelitian hukum normatif dan penelitian hukum empiris dengan bahan hukum primer dan sekunder. Hasil penelitian ini menunjukkan bahwa 1) Faktor-faktor yang mempengaruhi kepadatan kapasitas di dalam Lapas yaitu; Pertama, tingginya tingkat Kriminalitas dan Kedua, Kebijakan Peradilan Hukum Pidana. (2) Kebijakan yang dilakukan oleh Lapas Wirogunan ialah dengan mengoptimalkan dengan program terintegrasi di dalam Lapas. (3) Formulasi pidana dan pemidanaan yang dapat dilakukan ialah pertama merevisi KUHP yang semula berprinsip komulasi menjadi prinsip pidana yang memiliki konsep alternatif, yang kedua merubah pandangan hakim yang cenderung menjatuhkan pidana penjara menjadi adanya pidana alternative lain dalam KUHP. Ketiga, pemerintah menambah Lapas di Indonesia, sehingga formulasi ini mampu menekan adanya tindak pidana.
\end{abstract}

\section{Kata kunci: Lembaga Pemasyarakatan, Kebijakan, Pidana dan Pemidanaan}

\begin{abstract}
The researcher will identify Wirogunan Correctional Facility policy in preventing overcapacity in it and also how their criminal formulations and punishments to decrease it in this Facility. This research used normative law method and empirical law method and also used primary and secondary law materials. After that, this research shows us many results, there are: 1. Some factors which affect over-capacity in this Facility, there are: Criminal level increased and Criminal law of justice policy. 2. The aim of Wirogunan Facility is to optimize it through integrated program in this Facility. Then 3. The way to revise Law Formulations and Punishments are; first, revised the early Criminal Code which changed from Cumulations into any Criminal Principles having alternative concepts, then changed law POV (Point Of View) which acts to discriminate criminal jail into any criminal alternative in the Criminal Code (KUHP). And the last, government must build more Correctional Facilities in Indonesia, so that this formulation can push any crimes.
\end{abstract}

\section{Keywords: Correctional Facilities, Policy, Crime and Punishment}

\section{A. PENDAHULUAN}

\section{Latar Belakang}

Pidana adalah suatu reaksi atas delik, dan berwujud suatu nestapa yang dengan sengaja ditimpakan Negara pada pembuat delik. Nestapa yang ditimpakan kepada 
pembuat delik bukanlah suatu tujuan yang terahir di cita-citakan masyarakat, tetapi nestapa hanyalah suatu tujuan yang terdekat. Sehingga hukum pidana dalam usahanya untuk mencapai tujuan-tujuannya tidaklah semata-mata dengan jalan menjatuhkan pidana, tetapi dengan jalan menggunakan tindakan-tindakan. Sehingga tindakan dapat dipandang sebagai sanksi, tetapi tidak bersifat pembalasan, dan ditujukan semata-mata pada prevensi khusus, dan tindakan dimaksudkan untuk menjaga keamanan masyarakat terhadap ancaman bahayanya. ${ }^{1}$

Pidana penjara adalah suatu bentuk pidana yang berupa pembatasan gerak yang dilakukan dengan menutup pelaku tindak pidana dalam sebuah Lembaga Pemasyarakatan, dengan mewajibkan orang itu untuk mentaati semua peraturan tata tertib yang berlaku dalam Lembaga Pemasyarakatan, yang dikaitkan dengan aturan atau tata tertib bagi pelaku tindak pidana yang melanggar peraturan tersebut. ${ }^{2}$

Pelaksanaan dari sanksi pidana yang ada saat ini belum dapat mengurangi angka kejahatan, karena pelaksaan sanksi pidana itu menimbulkan adanya kepadatan dalam Lembaga Pemasyarakatan. Persoalan kepadatan Lembaga Pemasyarakatan saat ini sangat menarik perhatian kita, dimana dapat kita lihat dengan jumlah penghuni narapidana diseluruh Lembaga Pemasyarakatan di Indonesia, sebagai berikut:

Tabel 1.

Data Terahir Jumlah Warga Binaan Pemasyarakatan Perkanwil Tahun 2017

\begin{tabular}{|l|l|l|l|l|}
\hline No & Satuan Kerja & Total & Kapasitas & \% Over Kapasitas \\
\hline 1 & Kanwil Aceh & 7258 & 4347 & 67 \\
\hline 2 & Kanwil Bali & 2728 & 1394 & 96 \\
\hline 3 & Kanwil Bangka Belitung & 2148 & 1253 & 71 \\
\hline 4 & Kanwil Banten & 8427 & 4659 & 81 \\
\hline 5 & Kanwil Bengkulu & 2352 & 1487 & 58 \\
\hline 6 & Kanwil D.I. Yogyakarta & 1597 & 1920 & 0 \\
\hline 7 & Kanwil Dki Jakarta & 16248 & 5851 & 178 \\
\hline 8 & Kanwil Gorontalo & 826 & 767 & 8 \\
\hline 9 & Kanwil Jambi & 3811 & 1986 & 92 \\
\hline 10 & Kanwil Jawa Barat & 22185 & 16060 & 38 \\
\hline 11 & Kanwil Jawa Tengah & 12257 & 9109 & 35 \\
\hline 12 & Kanwil Jawa Timur & 23353 & 11684 & 100 \\
\hline 13 & Kanwil Kalimantan Barat & 4612 & 2405 & 92 \\
\hline
\end{tabular}

1 Syaiful Bakhri, Perkembangan Stelsel Pidana Indonesia, Yogyakarta: Total Media, , 2002, hlm. 1

2 Andi Hamzah, Sistem Pidana dan Pemidanaan di Indonesia, Jakarta: Pradnya Paramita, 1993, hlm 27. 


\begin{tabular}{|l|l|l|l|l|}
\hline 14 & Kanwil Kalimantan Selatan & 8874 & 3347 & 165 \\
\hline 15 & Kanwil Kalimantan Tengah & 3753 & 1868 & 101 \\
\hline 16 & Kanwil Kalimantan Timur & 10500 & 2928 & 259 \\
\hline 17 & Kanwil Kepulauan Riau & 4409 & 2537 & 74 \\
\hline 18 & Kanwil Lampung & 7774 & 3970 & 96 \\
\hline 19 & Kanwil Maluku & 1112 & 1303 & 0 \\
\hline 20 & Kanwil Maluku Utara & 973 & 1407 & 0 \\
\hline 21 & Kanwil Nusa Tenggara Barat & 2756 & 1103 & 150 \\
\hline 22 & Kanwil Nusa Tenggara Timur & 3229 & 2751 & 17 \\
\hline 23 & Kanwil Papua & 1856 & 2137 & 0 \\
\hline 24 & Kanwil Papua Barat & 985 & 936 & 5 \\
\hline 25 & Kanwil Riau & 10452 & 3637 & 187 \\
\hline 26 & Kanwil Sulawesi Barat & 755 & 868 & 0 \\
\hline 27 & Kanwil Sulawesi Selatan & 8751 & 5796 & 51 \\
\hline 28 & Kanwil Sulawesi Tengah & 2816 & 1589 & 77 \\
\hline 29 & Kanwil Sulawesi Tenggara & 2492 & 1966 & 27 \\
\hline 30 & Kanwil Sulawesi Utara & 2662 & 2183 & 22 \\
\hline 31 & Kanwil Sumatera Barat & 4649 & 3109 & 50 \\
\hline 32 & Kanwil Sumatera Selatan & 12189 & 6166 & 98 \\
\hline 33 & Kanwil Sumatera Utara & 28601 & 10732 & 167 \\
\hline Sumber: Direktorat Jendral Pemasyaratan "Laporan & Sistem Data & Base Pemasyarakata"” \\
\hline
\end{tabular}

Sumber: Direktorat Jendral Pemasyarakatan "Laporan Sistem Data Base Pemasyarakatan" http://smslap.ditjenpas.go.id/public/gr//current/monthly, diakses pada Tanggal 08 Oktober 2017.

Berdasarkan hal diatas bahwasanya adanya kelebihan kapasitas Lembaga Pemasyarakatan sangat berpengaruh dalam Lembaga Pemasyarakatan menyebabkan terjadinya suatu tindak pidana, maka berangkat dari uraian diatas penulis berniat untuk melakukan sebuah penelitian Kebijakan Kriminal dalam Menanggulangi Kelebihan Kapasitas Lembaga Pemasyarakatan.

\section{Rumusan Masalah}

Faktor-faktor apa saja yang mempengaruhi kelebihan kapasitas (over capacity) di Lembaga Pemasyarakatan? Bagaimanakah Kebijakan Lembaga Pemasyarakatan Wirogunan untuk Menanggulangi Potensi Kelebihan Kapasitas Lembaga Pemasyarakatan? Bagaimanakah formulasi pidana dan pemidanaan di masa yang akan datang untuk menanggulagi kelebihan kapasitas (over capacity) di Lembaga Pemasyarakatan? 


\section{Metode Penelitian}

Menurut jenis, sifat dan tujuannya penelitian hukum dibedakan atas penelitian hukum normatif dan penelitian hukum empiris. ${ }^{3}$ Jenis yang akan digunakan dalam penelitian ini adalah penelitian hukum normatif (yuridis normative) dan penelitian hukum empiris, penelitian hukum normatif yang dilakukan dengan cara meneliti bahan pustaka atau data sekunder dan empiris dilakukan penelitian lapangan. ${ }^{4}$

Analisis data merupakan kegiatan mengkaji atau menelaah hasil pengolahan data yang dibantu dengan teori-teori yang diperoleh sebelumnya. ${ }^{5}$ Terhadap suatu penelitian sangat diperlukan suatu analisis data yang berguna untuk memberikan jawaban terhadap permasalahan yang diteliti. Analisis data dalam penelitian ini menggunakan metode kualitatif. Penelitian dengan menggunakan metode kualitatif bertolak dari asumsi tentang realitas atau fenomena sosial yang bersifat unik dan komplek padanya terdapat regularitas atau pola tertentu, namun penuh dengan variasi (keragaman).

\section{B. HASIL DAN PEMBAHASAN}

\section{Faktor-faktor yang mempengaruhi yang mempengaruhi kelebihan kapasitas} (over capacity) di Lembaga Pemasyarakatan

Menurut Kepala Seksi Pembinaan Narapidana di Lapas Wirogunan Faktor-faktor yang mempengaruhi yang mempengaruhi kelebihan kapasitas (over capacity) di Lembaga Pemasyarakatan adalah sebagai berikut:

a. $\quad$ Tingkat Kriminalitas/Kejahata yang ada di dalam masyarakat. ${ }^{6}$

Berbicara tentang kejahatan harus terlebih dahulu melihat dari sudut mana kejahatan itu ditinjau. ${ }^{7}$ Secara umum pada dasarnya pengertian kejahatan ini diberikan pada suatu jenis atau tingkah laku manusia tertentu yang dapat dinilai sebagai perbuatan jahat. Oleh karena perbuatan jahat bertolak ukur pada alam nilai, tentunya penafsiran yang diberikan pada perbuatan atau tingkah laku itu sangat relatif sekali. Sahetapy menyatakan bahwa sampai sekarang belum dapat diberikan jawaban yang memuaskan

3 Bambang Waluyo, Penelitian Hukum dalam Praktik, Jakarta: Sinar Grafika, 2002, hlm. 13

4 Soerjono Soekanto dan Sri Mamudji, Penelitian Hukum Normatif Suatu Tinjauan Singkat, Jakarta: Raja Grafindo Persada, 2006, hlm.13-14.

5 Soerjono Soekanto, Pengantar Penelitian Hukum, Jakarta: Universitas Press, 1986, hlm.201.

6 Ibid.

7 Chainur Arrasjid, Sepintas Lintas tentang Politik Kriminal, Medan: Kelompok Studi Hukum dan Masyarakat Fakultas Hukum USU, 1999, hlm. 39. 
mengapa orang melakukan kejahatan dan mengapa setelah orang tersebut dipidana mati (untuk kejahatan tertentu) masih ada orang lain yang melakukan kejahatan yang sama. ${ }^{8}$ Berbicara mengenai mengapa orang melakukan kejahatan adalah tepat apa yang dikatakan oleh Mardjono Reksodiputro bahwa pengetahuan kriminologi dewasa ini belum sampai memungkinkan untuk dengan tegas menentukan sebab-sebab orang melakukan pelanggaran norma (hukum). ${ }^{9}$

b. Kebijakan Peradilan Hukum Pidana ${ }^{10}$

Memang, kebijakan peradilan hukuman pidana telah berdampak pada pertumbuhan populasi penjara dan kepadatan di penjara di sejumlah besar negara. Pengadilan di banyak negara saat ini lebih cenderung memberikan hukuman penjara pada pelaku pelanggaran dan menjatuhkan hukuman lebih lama daripada yang mereka lakukan satu dekade yang lalu. Di banyak negara, pelaku non-kekerasan yang melakukan kejahatan kecil kemungkinan dihukum penjara, bukannya ditangani pada tahap pertama proses peradilan pidana dengan memberikan peringatan, denda, atau hukuman yang ditangguhkan, atau tindakan peradilan restoratif. Alternatif nonpenahanan-berbasismasyarakat sering diabaikan demi perampasan kebebasan. ${ }^{11}$

Upaya penegakan hukum melalui kebijakan peradilan hukum pidana yang memberikan sanksi kepada pelaku tidak akan mengurangi tindak pidana. Semakin banyak pelak yang dikenakan sanksi oleh peradilan pidana makan akan menyebabkan padatnya Lapas, sebagaimana menurut teori Von Feurbach bahwa tujuan pidana yang bersifat prventif menyatakan bahwa sifat menakutnakuti ancaman pidana bukanlah pada penjatuhan pidana in concreto akan tetapi hanya berdasarkan kepada peraturan perundangundangan saja. ${ }^{12}$

Berdasarkan uraian di atas menunjukkan bahwasanya faktor-faktor lain yang menyebabkan kepadatan Lapas tidak hanya tingkat kriminalitas itu sendiri tetapi faktor lain yang mendukung terjadinya kepadatan Lapas ialah dengan meningkatnya jumlah pelaku tindak pidana yang dijatuhi oleh kebijakan peradilan hukum dengan memberikan

8 J. E. Sahetapy, 1992, Suatu Studi Khusus mengenai Ancaman Pidana Mati terhadap Pembunuhan Berencana, Rajawali Pers, Jakarta, hlm. 180.

9 Mardjono Reksodiputro, Kriminologi dan Sistem Peradilan Pidana, Jakarta: Kumpulan Karangan, Pusat Pelayanan Keadilan dan Pengabdian Hukum (Lembaga Kriminologi) UI, 1994, hlm. 3.

10 United Nations Office On Drugs And Crimes (Kantor Pbb Untuk Narkoba Dan Kejahatan), 2013, Panduan Tentang Strategi Untuk Mengurangi Kepadatan Di Penjara, Komite Internasional Palang Merah (ICRC), Jenewa, hlm. 26.

11 Ibid.

12 Adami Chazawi, Op.Cit, hlm. 163 
hukuman pidana penjara. Sehubungan dengan itu maka tingkat kriminalitas dan kebijakan peradilan hukum pidana sangatlah dominan dalam memicu tingginya tingkat kepadatan Lapas.

\section{Kebijakan Lembaga Pemasyarakatan Wirogunan untuk Menanggulangi Potensi Kelebihan Kapasitas Lembaga Pemasyarakatan}

Kebijakan yang dilakukan oleh pihak Lapas Wirogunan Kota Yogyakarta dalam menanggulangi kelebihan kapasitas di dlaam lembaga pemasyarakatan ialah dengan cara mengoptimalkan Program Pembinaan Terintegrasi di Dalam Lapas yaitu sebagai berikut. $^{13}$

\section{a. Asimilasi}

Proses pembinaan warga binaan dan anak didik pemasyarakatan yang dilaksanakan dengan membaurkan warga binaan dan anak didik pemasyarakatan di dalam kehidupan masyarakat.

b. Pembebasan bersyarat

Pembebasan bersyarat adalah proses pembinaan narapidana dan anak pidana di luar Lembaga Pemasyarakatan setelah menjalani sekurang-kurangnya 2/3 (dua pertiga) masa pidananya 9 (sembilan) bulan. Tujuan dari adanya pembebasan bersyarat adalah untuk memudahkan narapidana untuk berkelakuan baik selama masa hukumannya di penjara. Pada dasarnya pembebasan bersyarat memberikan kesempatan bagi narapidana untuk lebih cepat menbaur dengan masyarakat dengan cara menjalani sisa waktu hukumannya di luar lembaga pemasyarakatan. Diberikan kepada wbp dengan hukuman di atas 1 tahun, setelah menjalani $2 / 3$ masa pidana sekurang-kurangnya 9 bulan berkelakuan baik.

c. Cuti menjelang bebas

Cuti menjelang bebas adalah proses pembinaan narapidana dan anak pidana di luar Lapas setelah menjalani 2/3 (dua pertiga) masa pidana dan selama menjalani masa pidana tersebut narapidana berkelakuan baik sekurang- kurangnya selama 9 (sembilan) bulan dari masa pengajuan usulan cuti menjelang bebas terhadap dirinya. Untuk memperoleh cut menjelang bebas, narapidana harus memenuhi persyaratan. Yang membedakan adalah syarat substansif yaitu telah menjalani 2/3 (dua pertiga) dari masa

13 Wawancara dengan Bapak Heriyanto dan Ibu Kandi Tri Susilaningsih, Kepala Seksi dan Staff Pembinaan di Lapas Wirogunan, Pada Hari Selasa 19 Desember 2017. 
pidananya da jangka cuti sama dengan remisi terakhir paling lama 6 (enam) bulan. Diberikan kepada wbp setelah menjalani 2/3 masa pidana sekurang-kurangnya 9 bulan berkelakuan baik, jumlahnya sebesar jumlah remisi terakhir.

d. Cuti bersyarat

Cuti bersyarat adalah proses pembinaan di luar Lapas bagi narapidana dan anak pidana yang dipidana 1 (satu) tahun ke bawah, sekurang-kurangnya telah menjalani $2 / 3$ (dua pertiga) masa pidana. Untuk proses pembinaan ini, narapidana harus memenuhi persyaratan yang sama dengan pembebasan bersyarat dan cuti menjelang bebas namun yang membedakan ada pada syarat substansif yaitu berkelakuan baik selama menjalani pidana dan tidak pernah mendapatkan hukuman, disiplin sekurang-kurangnya dalam waktu 6 (enam) bulan terakhir dan masa pidana yang telah dijalani 2/3 (dua pertiga) dari masa pidananya dan jangka waktu paling lama 3 (tiga) bulan dengan ketentuan apabila selama menjalani cuti melakukan tindak pidana baru selama di luar Lapas tidak dihitung sebagai masa menjalani pidana. Diberikan kepada wbp dengan hukuman dibawah 1 tahun, setelah menjalani 2/3 sekurang-kurangnya 6 bulan, jumlahnya maksimal 3 bulan.

Sehubungan dengan program terintegrasi diatas yang sesuai dengan rumusan di dalam peraturan perundang-undang maka semua narapidana berhak mendapatkan program terintegrasi tersebut. Di dalam Lapas Wirogunan program terintegrasi ini sudah dijalankan dalam rangka mengurangi kapasitas kepadatan di dalam Lapas, adapun data yang dihimpun dari Lapas Wirogunan selama tahun 2017 yang mendapatkan program terintegrasi ialah sebagai berikut:

Tabel.4

Jumlah Narapidana yang mendapatkan Program Terintegrasi di Lembaga Pemasyarakatan Wirogunan Per Akhir Tahun 2017

\begin{tabular}{|l|l|l|l|l|l|}
\hline \multirow{2}{*}{ No } & \multicolumn{3}{|c|}{ Penghuni lapas yang mendapatkan } & \multirow{2}{*}{ Jumlah } \\
\cline { 2 - 5 } & $\begin{array}{l}\text { Pembebasan } \\
\text { Bersyarat (PB) }\end{array}$ & $\begin{array}{l}\text { Cuti menjelang } \\
\text { bebas (CMB) }\end{array}$ & $\begin{array}{l}\text { Cuti Bebas } \\
\text { (CB) }\end{array}$ & $\begin{array}{l}\text { Bebas } \\
\text { Murni }\end{array}$ & \\
\hline 1 & 33 Orang & 2 Orang & 9 Orang & $\begin{array}{l}57 \\
\text { Orang }\end{array}$ & 98 Orang \\
\hline
\end{tabular}

Sumber; Data Primer yang diambil dari Lapas Wirogunan, data diolah

Berdasarkan data diatas bahwa program terintegrasi di dalam lapas wirogunan sudah dijalankan sedemikian rupa, adapun yang menjadi alasan dari pihak lapas 
wirogunan memberikan program ini dengan sesegera mungkin diberikan kepada para narapidana yang sudah memenuhi persyaratan yang sudah dijelaskan diatas, maka narapidana tersebut langsung dipromosikan oleh pihak lapas untuk mendapatkan program-program yang sudah ada tersebut. ${ }^{14}$

Melalui data di atas dapat dilihat bahwasanya program terintegrasi ini mampu mengatasi kepadatan lapas. Di lapas wirogunan sendiri sepanjang tahun 2017 tidak mengalami yang namanya kepadatan lapas, karena di dalam lapas wirogunan selalu mengutamankan program ini untuk memotivasi para narapidana agar tidak berlamalama di dalam lapas, ketika narapidana semakin lama di lapas maka akan semakin padatlah lapas tersebut. Jumlah penghuni lapas wiroguna pada tahun 2017 berjumlah sebanyak 353 Orang. Jumlah 353 orang ini sudah dikurangi dari jumlah narapidana yang medapatkan program terintegrasi sesuai dengan data yang ada diats yaitu sebanyak 98 orang.

Sehubungan dengan data diatas juga lapas wirogunan mampu menekan angka kepadatan di dalam lapas, ini disebabkan karena di Lapas wirogunan selalu memberikan program terintegrasi kepada seluruh narapidana, bahkan ketika narapidana pertama kali masuk kedalam lapas, pihak lapas telah memberikan pengarahan dan motivasi kepada seluruh narapinan untuk bias mendapatkan program terintegrasi tersebut secepat mungkin. Menurut penulis adapun salah satu cara untuk menguragi kepadatan di dalam lapas yaitu dengan mengoptimalkan program ini sebaik dan secepat mungkin kepada seluruh narapidana yang ada di dalam lapas tentunya harus sesuai dengan aturan yang ada dan tanpa adanya jual beli program ini kepada narapidana.

\section{Formulasi pidana dan pemidanaan di masa yang akan datang untuk mengatasi kelebihan kapasitas Lembaga Pemasyarakatan}

Menurut Bapak Supriyadi adapun Formulasi pidana dan pemidanaan di masa yang akan datang untuk mengatasi kelebihan kapasitas Lembaga Pemasyarakatan sebagai berikut: ${ }^{15}$

A. Formulasi Pidana dan pemidanaan harus dibuat secara Alternatif

Untuk mengurangi adanya over kapasitas secara penal dapat dilakukan dengan

14 Wawancara dengan Bapak Heriyanto dan Ibu Kandi Tri Susilaningsih, Kepala Seksi dan Staff Pembinaan di Lapas Wirogunan, Pada Hari Selasa 19 Desember 2017.

15 Wawancara dengan Bapak Supriyadi, Op.Cit. 
mencari suatu alternatif penjatuhan pidana. Upaya ini perlu dilakukan dimana pada saat ini pidana perampasan kemerdekaan (pidana penjara) sedang mengalami masa krisis karena termasuk salah satu jenis pidana yang kurang disukai. Banyak kritik tajam ditujukan terhadap jenis pidana perampasan kemerdekaan ini, baik dilihat dari sudut efektivitasnya maupun dilihat dari akibat- akibat negatif lainnya.

Berdasarkan hasil wawancara dengan Staff Pembinaan di Lapas Wirogunan Lapas sekarang tidak lagi cukup untuk menampung jumlah warga binaan yang ada, walaupun terdapat beberapa sarana yaitu tempat ibadah, sarana olah raga, areal pertanian, sel tidur dan kamar mandi, tempat bimbingan kerja. Dengan jumlah narapidana yang ada di Lapas Wirogunan saat ini sarana dan prasarana yang saat ini tidak lagi mencukupi untuk dilakukannya pembinaan secara maksimal. Berdasarkan pengamatan penulis, kegiatan narapidana seputar makan, olah raga (jika mau, sesuai dengan bakatnya), mengikuti acara keagamaan, dan bimbingan kerja seperti membuat perabotan (kursi, meja, lemari), ada narapidana yang bercocok tanam seperti jagung, kangkung, dan bayam. ${ }^{16}$

Dalam hal ini pidana penjara juga mendapat persoalan seberapa jauh efektivitasnya dalam rangka pencegahan kejahatan. Pidana penjara mendapat kritik yang sangat tajam baik di Indonesia maupun negara-negara lain mengenai pelaksanaannya. Terdapat berbagai hasil penelitian yang mengemukakan bahwa pidana penjara sangat merugikan baik terhadap individu yang dikenai pidana maupun terhadap masyarakat. Oleh karena itu terdapat usaha dari para ahli untuk mencari bentuk pidana lain sebagai alternatif dari pidana penjara ini, diantaranya:

\section{a. Pidana Pengawasan}

Pidana alternatif yang ditawarkan oleh narasumber Bapak supriyadi ialah dengan menambahkan adanya pidana Pengawasan dimasukkan dalam formulasi peraturan -perundang-undangan hokum pidana kedepannya, sebenarnya pidana pengawasan ini sudah ada sebelumnya sebelumnya di dalam KUHP warisan kolonial Belanda adalah dikenal dengan nama pidana bersyarat, dimana Soesilo menggunakan istilah hukuman dengan perjanjian atau hukuman dengan bersyarat atau "hukuman jagelan", yang diatur dalam pasal 14 a sampai 14 f KUHP, dan pelepasan bersyarat sebagaimana diatur dalam pasal 15 sampai dengan 17

16 Wawancara dengan Bapak Heriyanto dan Ibu Kandi Tri Susilaningsih, Kepala Seksi dan Staff Pembinaan di Lapas Wirogunan, tanggal 13 Januari 2018. 


\section{KUHP. ${ }^{17}$}

Pidana pengawasan merupakan jenis pidana baru yang sebelumnya diatur dalam KUHP. Penjatuhan pidana pengawasan tidak sembarang dapat dilakukannamun harus memenuhi persyaratan tertentu. ${ }^{18}$

Menurut dari Kepala Seksi Pembinaan Lapas wirogunan pidana pengawasan ini adalah salah satu formulasi pidana yang sangat relevan untuk diterapkan dalam kehidupan dewasa ini, sebab melihat banyaknya fenomena yang terjadi di dalam Lapas yang sedemikian rumit untuk diselesaikan bahkan mampu menghabiskan seluruh energi yang terlibat di dalamnya menjadi tidak efektif lagi untuk diterapkan, maka dengan kehadiran pidana pengawasan ini menajdi salah satu jawaban dari kegelisahan dari pihak lembaga pemasyarakatan akan kepadatan lemabaga pemasyarakatan, walaupun ini semua harus dipersiapkan dengan sebaik mungkin agar tidak menimbulkan adanya kesalahan-kesalahan yang mengakibatkan sistem menajdi tidak sedemikian kalanya. ${ }^{19}$

Hasil dari penelitian diatas bahwa penulis menganalisa bahwa dengan diberlakukannya pidana pengawasan ini, setidaknya mampu mengatasi/mengurangi adanya paradigm hakim kedepan untuk tidak lagi beranggapan bahwa pelaku kejahatan harus masuk kedalam penjara tetapi bisa diubah kearah pidana pengawasan yang kelak akan menjadi penyeimbang untuk mejatuhkan pidana kepada pelaku kejahatan dimasa yang akan datang.

b. Pidana Kerja Sosial

Adapun usulan yang keempat dalam mengatasi kepadatan Lapas adalah dengan menerapkan danya pidana kerja social yang. Pidana kerja sosial dapat diterapkan sebagai alternatif pidana penjara jangka pendek dan denda yang ringan. ${ }^{20}$ Secara sederhana pidana kerja sosial dapat diartikan sebagai pidana yang dijalani oleh terpidana dengan melakukan pekerjaan sosial yang ditentukan. Dalam wacana istilah hukum pidana, istilah pidana kerja sosial lazim diterjemahkan dalam bahasa Inggris dengan istilah Community Service Order. Berbeda dengan jenis pidana perampasan kemerdekaan, pidana ini merupakan

\footnotetext{
17 Wawancara dengan Bapak Supriyadi, Op.Cit.

18 Bambang Waluyo, Pidana dan Pemidanaan, Jakarta: Sinar Grafika, 2000, hlm. 19.

${ }^{19}$ Wawancara dengan Bapak Heriyanto Kepala Seksi Pembinaan 13 Januari 2018

${ }^{20}$ Niniek Suparni,1996, Eksistensi Pidana Denda dalam Sistem Pidana dan Pemidanaan, sinar Grafika, Jakarta.hlm, 36.
} 
jenis pidana yang harus dijalani terpidana di luar lembaga pemasyarakatan dengan melakukan pekerjaan-pekerjaan sosial. Pidana kerja sosial sebelumnya tidak diatur dalam KUHP. Pokok-pokok dari pidana kerja sosial yang diatur dalam RUU KUHP adalah: ${ }^{21}$

1) Apabila pidana penjara yang dijatuhkan tidak lebih dari 6 bulan atau pidana denda yang dijatuhkan tidak lebih dari denda kategori I maka pidana penjara atau pidana denda tersebut dapat diganti dengan pidana kerja sosial.

2) Hal-hal yang harus dipertimbangkan oleh hakim dalam menjatuhkan pidana kerja sosial antara lain, pengakuan terdakwa tehadap tindak pidana yang dilakukan; usia layak kerja terdakwa menurut peraturan perundangundangan yang berlaku; persetujuan terdakwa sesudah dijelaskan mengenai tujuan dan segala hal yang berhubungan dengan pidana kerja sosial; riwayat sosial terdakwa; perlindungan keselamatan kerja terdakwa; keyakinan agama dan politik terdakwa; dan kemampuan terdakwa membayar denda.

3) Jika pidana kerja sosial sebagai pengganti denda maka sebelumnya harus ada permohonan terdakwa dengan alasan tidak mampu membayar denda tersebut. Pidana kerja sosial paling singkat 7 jam. Waktu pidana kerja sosial dijatuhkan paling lama:
a) 240 jam bagi terdakwa yang telah berusia 18 tahun ke atas.
b) 120 jam bagi terdakwa yang berusia di bawah 18 tahun.
c) Pelaksanaan pidana kerja sosial dapat diangsur paling lama 12 bulan dengan tetap memperhatikan:

- $\quad$ Kegiatan terdakwa dalam menjalankan mata pencahariannya dan atau;

- Kegiatan lain yang bermanfaat.

4) Apabila terdakwa gagal memenuhi seluruh atau sebagian kewajiban untuk menjalankan pidana kerja sosial tanpa alasan wajar maka terdakwa dapat diperintahkan;
a) Mengulangi seluruh atau sebagian pidana kerja sosial tersebut.
b) Menjalani seluruh atau sebagian pidana penjara yang diganti dengan pidana kerja sosial tersebut, atau

\footnotetext{
${ }^{21}$ Bambang Waluyo, op.cit., hlm, 20-21.
} 
c) Membayar seluruh atau sebagian pidana dengan yang tidak dibayar adalah yang diganti dengan pidana kerja sosial tersebut atau menjalani pidana penjara sebagi pengganti denda yang tidak dibayar.

Sebagai pidana alternatif, pidana kerja sosial mempunyai beberapa keunggulan antara lain:

1) Pidana kerja sosial sedikit banyak menisbikan proses stigmatisasi yang selalu menjadi efek pidana perampasan kemerdekaan. Proses stigmatisasi dalam banyak hal telah menempatkan seorang terpidana sebagai orang yang berlabel sebagai penjahat sekalipun orang tersebut tidak lagi melakukan kejahatan. Stigmatisasi ini pada gilirannya akan menghambat pembinaan narapidana. Tidak berhasilnya pembinaan narapidana karena efek negatif yang berupa stigmatisasi ini jelas akan melahirkan penjahat kambuhan.

2) Pidana kerja sosial akan meniadakan efek negatif berupa pendidikan kejahatan oleh penjahat. Sudah rahasia umum, bahwa lembaga pemasyarakatan seringkali berfungsi sebagai tempat kuliahnya para penjahat yang akan melahirkan penjahat yang lebih profesional.

3) Dilihat dari perspektif ekonomi, pidana kerja sosial juga jauh lebih murah dibandingkan pidana perampasan kemerdekaan. Dengan pidana kerja sosial, maka subsidi untuk biaya hidup narapidana di lembaga dapat ditekan yang pada akhirnya akan mengurangi beban masyarakat. ${ }^{22}$

Pilihan terhadap pidana kerja sosial juga sesuai dengan kecenderungan internasional yang sedang terjadi disamping tidak bertentangan dengan nilai-nilai yang ada dalam masyarakat Indonesia. Secara teoritis pidana kerja sosial dapat memenuhi tujuan pemidanaan yang ditetapkan. Pidana kerja sosial dapat memberikan perlindungan secara intergratif antara perlindungan masyarakat dan individu sebagaimana tujuan pemidanaan yang telah dirumuskan. ${ }^{23}$

\section{c. Menggunakan Sistem Diversi}

22 Wawancara dengan Bapak Heriyanto dan Ibu Kandi Tri Susilaningsih, Op.Cit.

23 Tongat, 2001, Pidana Kerja Sosial dalam Pembaharuan Hukum Pidana Indonesia, Djambatan, Jakarta, hlm, 51-52. 
Formulasi pidana dan pemidanaan alterlatif yang terahir diusulkan ialah dengan menerapkan sistem diversi yang aada di dalam rumusan Undang-Undang nomor 11 Tahun 2012 tentang Sistem Peradilan Pidana Anak. ${ }^{24}$ Barda Nawawi Arif menjelaskan perkembangan dan latar belakang munculnya ide mediasi penal sebagai pilihan penyelesaian perkara pidana yang terintegrasi dalam sistem peradilan pidana.

Menurut penulis penerapan sistim diversi yang ada di dalam UndangUndang nomor 11 Tahun 2012 tentang Sistem Peradilan Pidana Anak ini bisa juga di terapkan kepada pelaku kejahatan yang pelakunya adalah orang desawa, sesuai dengan penjelasan diatas sebenarnya da peluang penerapan sistem diversi ini bisa diterapkan pada pelaku kejahatan orang desawa, tergantung bagaimana penerapannya ini bisa berjalan dengan baik, maka peran dari pemerintah untuk mebuat formulasi yang sesuai dengan perkembangan zaman yanga ada saat ini, agar pemberlakuan sistem ini bisa diterapkan dengan pelaku orang dewasa.

\section{B. Paradigma Hakim Dalam Memutus Perkara di Pengadilan}

Upaya yang lain yang bisa dilakukan untuk dapat mengurangi danya kelebihan kapasitas di dalam lapas ialah dengan mengubah adanya paradigm hakim dimasa yang akan datang. ${ }^{25}$ Hakim memiliki kedudukan dan peranan yang sangat penting dalam penegakan hukum di Negara Indonesia. Sebagaimana telah disebut dimuka dalam UUD 1945 dalam pasal 27 secara khusus ditegaskan dalam kekuasaan kehakiman pasal 24 dan 25. dijelaskan bahwa kekuasaan kehakiman adalah kekuasaan yang merdeka terlepas dari pengaruh luar. Hakim menjalankan pekerjaannya dengan menggunakan metode silogisme. Jika menghadapai suatu perkara yang diajukan padanya hakim harus mampu memperhatikan duduk perkaranya menurut berbagai sudut pandang para pihak yang terlibat. Jika peraturannya ada hakim tinggal menyesuaikan, akan tetapi jika peraturanya tidak ada hakim harus menggali nilai- nilai hukum yang ada karena hakim mempunyai kebebasan, tanggung jawab dan suara hati. Nilai-nilai hukum seperti persepsi masyarakat tentang keadilan, kepastian hukum dan kemanfaatan selalu berkembang setiap saat. Nilai nilai tadi selalu tarik menarik, sehingga pendulumnya

24 Wawancara dengan Bapak Supriyadi, Op.Cit.

25 Tina Asmarwati, Pidana dan Pemidanaan dalam Sistem Hukum di Indonesia, Yogyakarta: Deepublish, 2014, hlm. 12. 
suatu saat dekat dengan keadilan, tetapi saat yang lain dekat dengan kepastian hukum/kemanfaatan. Hakim harus mampu menangkap nusansa seperti itu. ${ }^{26}$

Jangan sampai hakim salah dalam menerapkan sanksi pidana. harus sesuai dengan kesalahan terdakwa. Penerapan pidana dalam pemidanaan bersifat universal, sulit menentukan standard pemidanaan dalam penjatuhan pidana. Guna mengatasi hal-hal semacam ini, para Hakim diharapkan agak membuka diri dan mengambil inisiatif membentuk semacam Judicial Sentencing Institutes, forum pertemuan para Hakim yang memungkinkan mereka untuk mengadakan diskusi, dengan partisipasi dari pejabatpejabat pemasyarakatan dan kalangan ilmu pengetahuan. ${ }^{27}$

Sehubungan dengan hasil di atas maka perlunya sebenarnya merubah paradigm hakim dalam memutuskan suatu perkara dipengadilan yang berkaitan dengan perkara pidana, sebab yang terjadi akhir-akhir ini ialah semakin banyak terjadi kejahatan maka semakin banyak yang akan mendapatkan hukuman pidana penjara, dengan demikian maka bertambah padatlah lapas di Indonesia. Usulan ini sangatlah mendukung dalam mengurangi kepadatan lapas sebab yag menjadi akhir dari nasip seorang terdakwa adalah ketika hakim menjatuhkan sebuah hokum kepadanya, maka dengan mengubah paradigm hakim yang semula yang biasanya menjatuhkan pidana hanya berujung kepada penghilangan kemerdekaan pelaku kejahatan maka dimasa yang akan datang perlu adanya suatu pidana alternative yang diberikan dalam formulasi peraturan perundang-undangan agar paradigm ini dapat berganti kearah dimana tidak lagi mengarah kepada satu pdiana yaitu pidana penjara.

\section{Membangun Lembaga Pemasyarakatan yang Baru}

Sebenarnya salah satu cara yang paling akhir untuk mengurangi padatnya lapas ialah dengan menambah lapas-lapas baru di Indonesia, tetapi hal itu tidak segampang memutar balikkan tangan, sebab banyak hal-hal yang harus diperkirakan kedepan dalam hal pembangunan Lapas di seluruh penjuru Indonesia. Seperti yang dihimpun di dalam berita Sindo di atas maka penambahan Lapas sudah diwacanakan oleh pemerintah untuk tahun iini tetapi yang menjadi kedala terbesar ialah pendanan dan Alokasi dimana Lapas akan dibangun.

\footnotetext{
26 Tina Asmarwati, Op.Cit, hlm. 19-20.

27 Muladi dalam Tina Asmarwati, Op.cit, hlm. 21.
} 
Persoalan penambahan lapas merupakan persoalan yang akan menambah beban di dalam penegakan hukum Indonesia, sebab apabila semakin banyak Lapas di negeri ini maka bias dipastikan bahwa Negara Indonesia adalah sarangnya para pelaku tindak pidana. Tetapi ini juga yang akan menjaga persoalan apabila Lapas tidak dibangun lagi atau di tambah maka akan menyebabkan adanya suatu kelebihan kapasitas. Maka dari hasil pengamatan penulis bahwa untuk mengurangi adanya gesekan yang semakin parah di dalam Lapas maka perlu adanya penambahan Lapas di Indoensia untuk mengurangi adanya kelebihan kapsitas di dalam lapas.

\section{SIMPULAN}

Dari hasil penelitian maka diperoleh kesimpulan sebagai berikut:

1. Faktor-faktor yang mempengaruhi kepadatan kapasitas di dalam Lapas yaitu yang pertama ialah tingginya tingkat Kriminalitas menjadi faktor yang sangat dominan dalam kepadatan sebuah Lapas, maka dari itu kriminalitas harus ditekan sekecil mungkin bahkan kriminalitas harus segera dipulihkan dan tidak terjadil di dalam masyarakat, sebab semakin tinggi tingkat kriminalitas maka semakin banyak yang akan dikenakan sanksi di pengadilan. Yang kedua ialah Kebijakan Peradilan Hukum Pidana, dalam hal ini dengan meningkatnya jumlah pelaku tindak pidana yang dijatuhi oleh kebijakan peradilan hukum dengan memberikan hukuman pidana penjara, maka akan menyebabkan padatnya Lapas.

2. Kebijakan yang dilakukan oleh Lapas wirogunan dalam menganggulangi kepadatan kapasitas lapas ialah dengan mengotipmalkan program-program di dalam lapas yaitu program terintegrasi di dalam Lembaga Pemasyarakatan, dengan berjalan dengan efektifnya program ini maka akan menekan yang namanya kepadatan Penghuni Lembaga Pemasyarakan, sebab semakin banyak yang mendapatkan Program ini maka akan mempercepat pidana penjara yang di dapatkan oleh Penghuni Lembaga Pemasyarakatan.

3. Formulasi pidana dan pemidanaan yang harus dilakukan untuk mengurangi kepadatan Lembaga Pemsyarakatan ialah melihat kepada 5 aspek yaitu (a), berkaitan dengan Formulasi Peraturan perundang-undangannya harus dibuat dengan Sistem Pidana dan Pemidanaan secara Alternatif, yaitu seperti a) pidana Pengawasan, b) pidana Kerja Sosial, dann (c) Mengoptimalkan sistim Diversi. (b) 
merubah paradigma hakim yang saat ini agar tidak selalu menjatuhkan Pidana penjara sebagai salah satu alat penjeraan bagi si pelaku tindak pidana, (c) mengoptimalkan program-program di dalam lapas, dan terahir ialah (d) membangun Lapas Baru, sehingga dengan ada nya formulasi pidanda dan pemidanaan yang secara alternatif maka akan menekan pula angka residivis di dalam Lapas.

\section{DAFTAR PUSTAKA}

\section{Buku:}

A. Z. Abidin, Farid dan A. Hamzah. 2006. Bentuk-bentuk Khusus Perwujudan Delik (Percobaan, Penyertaan, dan Gabungan Delik) dan Hukum Penitensier. Jakarta: PT Raja Grafindo Persada

AR, Suhariyono. 2012. Pembaruan Pidana Denda di Indonesia (Pidana Denda Sebagai Sanksi Alternatif). Jakarta: Papas Sinar Sinanti

Arief, Barda Nawawi. 1994. Kebijakan Legislatif dalam Penanggulangan Kejahatan dengan Pidana Penjara. Semarang: CV. Ananta . 1996. Kebijakan Legislatif Dalam Penanggulangan Kejahatan 2002. Bunga Rampai Kebijakan Hukum Pidana. Bandung: Citra Aditya Bhakti

Arrasjid, Chainur. 1999, Sepintas Lintas tentang Politik Kriminal, Medan: Kelompok Studi Hukum dan Masyarakat Fakultas Hukum USU

Asmarwati, Tina. 2014. Pidana dan Pemidanaan dalam Sistem Hukum di Indonesia. Yogyakarta: Deepublish

Asmarwati, Tina. 2014. Pidana dan Pemidanaan dalam Sistem Hukum di Indonesia. Yogyakarta: Deepublish

Bakhri, Syaiful. 2002. Perkembangan Stelsel Pidana Indonesia. Yogyakarta: Total Media 
Hamzah, Andi. 1983. Suatu Tinjauan Ringkas Sistem Pemidanaan di Indonesia. Jakarta Akademi Pressindo

Hamzah, Andi. 1985. Sistem Pidana dan Pemidanaan Indonesia dari Retribusi ke Reformasi. Jakarta: Pradnya Paramita

Hamzah, Andi. 1993. Sistem Pidana dan Pemidanaan di Indonesia, Jakarta: Pradnya Paramita

Istanto, F. Sugeng. 2007. Penelitian Hukum. Yogyakarta: CV. Ganda

Reksodiputro, Mardjono. 1994. Kriminologi dan Sistem Peradilan Pidana Kumpulan Karangan. Jakarta: Pusat Pelayanan Keadilan dan Pengabdian Hukum (Lembaga Kriminologi) UI

Sahetapy, J. E. 1992. Suatu Studi Khusus mengenai Ancaman Pidana Mati terhadap Pembunuhan Berencana. Jakarta: Rajawali Pers

Soedarto. 1986. Hukum dan Hukum Pidana. Bandung: Alumni

Soekanto, Soerjono dan Sri Mamudji. 2006. Penelitian Hukum Normatif Suatu Tinjauan Singkat. Jakarta: Raja Grafindo Persada

Soekanto, Soerjono. 1986. Pengantar Penelitian Hukum, Jakarta: Universitas Press

Suparni, Niniek. 1996. Eksistensi Pidana Denda dalam Sistem Pidana dan Pemidanaan. Jakarta: Sinar Grafika

Tongat. 2001. Pidana Kerja Sosial dalam Pembaharuan Hukum Pidana Indonesia. Jakarta: Djambatan

United Nations Office On Drugs And Crimes (Kantor PBB Untuk Narkoba Dan Kejahatan). 2013. Panduan Tentang Strategi Untuk Mengurangi Kepadatan Di Penjara. Jenewa: Komite Internasional Palang Merah (ICRC)

Waluyo, Bambang. 2002. Penelitian Hukum dalam Praktik. Jakarta: Sinar Grafika 


\section{Peraturan Perundang-Undangan:}

Republik Indonesia, Undang-Undang Dasar Negara Republik Indonesia Tahun 1945

Republik Indonesia, Undang-Undang Nomor 12 Tahun 1995 tentang Pemasyarakatan

\section{Wawancara:}

Wawancara dengan Bapak Supriyadi, Dosen Fakultas Hukum Universitas Gadjah Mada.

Wawancara dengan Bapak Heriyanto dan Ibu Kandi Tri Susilaningsih, Kepala Seksi dan Staff Pembinaan di Lapas Wirogunan. 